\title{
ARTICLES
}

\section{Does Being a Repeat Player Make a Difference? The Impact of Attorney Experience and Case-Picking on the Outcome of Medical Malpractice Lawsuits}

Catherine T. Harris, ${ }^{*}$ Ralph Peeples, ${ }^{\dagger}$ and Thomas B. Metzloff ${ }^{\ddagger}$

INTRODUCTION

I. Predictors of Outcome in Medical Malpractice Cases: Previous

LITERATURE.

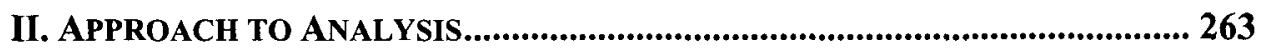

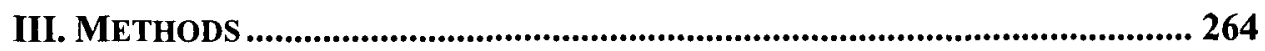

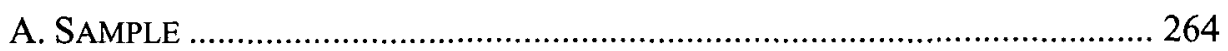

B. DePENDENT VARIABLE: CASE OUTCOME ……………………............... 266

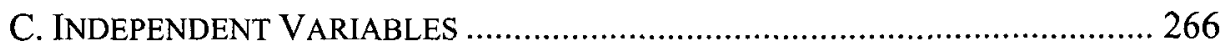

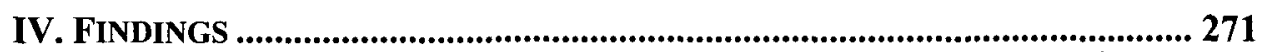

A. What Predicts Whether Money Will Be Paid to the Plaintiff? . 272

B. The EfFectiveness of Plaintiffs' Counsel and CASE-PICKING ........ 275

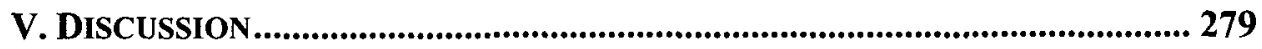

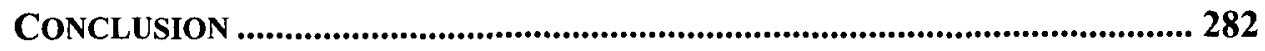

\footnotetext{
* Professor of Sociology, Wake Forest University. This research was supported with funding from the Robert Wood Johnson Foundation, Princeton, New Jersey, Grant I.D. \#027071.

${ }^{\dagger}$ Professor of Law, Wake Forest University School of Law

${ }^{\ddagger}$ Professor of Law, Duke University
} 


\section{INTRODUCTION}

Empirical analyses explaining litigation outcomes are not often attempted either in legal scholarship or in the sociology of law. ${ }^{1}$ There are studies focusing on conversation analysis in mediation, but few other empirical issues in litigation have been examined in depth. ${ }^{2}$ In addition, there is little theory addressing the causes of litigation outcomes in legal scholarship. ${ }^{3}$ Similarly, there are few micro-level studies or theories in the sociology of law, other than that of Donald Black, that address the litigation process. ${ }^{4}$

There are several reasons for the dearth of studies. Determining outcomes of actual, filed civil cases is difficult, tedious, and time-consuming. There are few databases from which samples may be drawn in a systematic way. Cases must be identified. Court records must be found, read, and abstracted. Critical information about cases is often not a part of the court file. For example, official court records seldom state whether a monetary settlement was reached, and, if so, the terms of that settlement. Instead, court records merely indicate either that the court rendered a judgment or dismissed the case. Why the case was dismissed, or on what terms the case was dismissed, is seldom disclosed.

Nonetheless, there is a great need for the insights to be gained from empirical studies based on court records supplemented by additional sources such as archival data, questionnaires, and interviews. Such studies could lead to a richer understanding of the conflict resolution process as it is conducted in the civil court system. The work of Miller and Sarat provides an example. ${ }^{5}$ More than twenty-five years ago, Miller and Sarat described the litigation process in the larger context of what they called the "dispute pyramid," with layers of grievances, claims, disputes, filings (involving lawyers), court filings, trials, and

1. There are a few exceptions, notably the work of Herbert Kritzer. However, Kritzer himself noted that there are few such studies. HERBERT KRITZER, LET's MAKE A DEAL 131 (1991).

2. Angela Garcia, Moral Reasoning in Interactional Contexts: Care and Justice Arguments in Mediation Hearings, 66 Soc. INQUIRY 197 (1996); David Greatbatch \& Robert Dingwell, Argumentative Talk in Divorce Mediation Sessions, 62 AM. Soc. REV. 151 (1997).

3. Marc Galanter is one of the few legal scholars who have offered a theoretical frame for understanding case outcomes from a socio-legal perspective. Galanter has pointed out that there is an awareness that little is known about how the tort liability system actually operates. Marc Galanter et al., How To Improve Civil Justice Policy, 77 JudiCATURe 185 (1994); Marc Galanter, Real World Torts: An Antidote to Anecdote, 55 MD. L. REv. 1093, 1098 (1996) [hereinafter Galanter, Real World Torts]; see also Michael Saks, Do We Really Know Anything About the Behavior of the Tort Litigation System-And Why Not?, 140 U. PA. L. REV. 1147, 1154-55 (1992).

4. Donald Black, Dreams of Pure Sociology, 18 Soc. THEORY 343 (2000); see also M.P. Baumgartner, The Sociology of Law in the United States, 32 AM. Soc. 99 (2001).

5. Richard Miller \& Austin Sarat, Grievances, Claims and Disputes: Assessing the Adversary Culture, 15 LAW \& SOC'Y REV. 525 (1981). 
appeals. They discussed the process of case attrition, ${ }^{6}$ and noted that this attrition may be pronounced. ${ }^{7}$ The result resembles a pyramid, with only the most durable cases rising through each layer to reach the top. The shape of the dispute pyramid varies by type of case, but what all these pyramids have in common is that very few cases survive to the apex-a pattern supported by considerable empirical evidence. ${ }^{8}$ Many, but not all, cases settle for money being paid to the plaintiff. Other cases are simply dropped prior to trial without any money being paid to the plaintiff. Thus, a successful plaintiff's lawyer must have the ability to select cases that are likely to settle or, if a trial occurs, that are likely to result in a plaintiff's verdict. ${ }^{9}$

Lack of understanding of the meaning or significance of various stages of the legal process impedes sociologists and social scientists in their attempts to analyze litigation. By their training, lawyers understand civil procedure-how a complaint is filed, how the lawsuit develops, how discovery works, how cases move towards resolution, how settlement happens, etc. To a sociologist or other social scientist, however, these processes may seem baffling, needlessly complicated, or obscure. Without a background in legal process, a researcher may not know what to investigate when she begins reading court records. But research conducted by lawyers or law professors suffers from serious shortcomings as well. Legal scholars rarely have expertise in empirical research methodologies or familiarity with the more systemic issues social scientists explore. A filed case is, after all, just a part of a larger puzzle. Why did some disputes between a patient and a physician turn into lawsuits? When a lawsuit is filed, what factors predict outcome? While lawyers, and perhaps physicians, may prefer to believe the merits alone predict outcome, there is ample reason to believe that the story is more complicated. ${ }^{10}$ For these sorts of questions, the analytical methods of sociologists become very valuable. Sociologists use a combination of theory, methods, and statistics to understand the impact of variables that influence behavior within a social system. In short, sociologists are trained to look for patterns.

Medical malpractice involves "turf conflicts" between professions and raises related organizational issues." These are areas in which sociologists have

6. Case attrition is inevitable. Disputes may be resolved prior to the retention of attorneys or conduct of a trial.

7. Miller \& Sarat, supra note 5, at 544-46.

8. KRITZER, supra note 1, at 178; Herbert Kritzer, Contingent Fee Lawyers As Gatekeepers in the Civil Justice System, 81 JUDICATURE 22, 29 (1997); Miller \& Sarat, supra note 5, at 544-46.

9. For a discussion of dispute pyramids, see Galanter, Real World Torts, supra note 3, at 1099-1102.

10. See, e.g., Catherine Harris, Ralph Peeples \& Thomas Metzloff, Placing "Standard of Care" in Context: The Impact of Witness Potential and Attorney Reputation in Medical Malpractice Litigation, 3 J. EMPIRICAL LEGAL STUD. 467, 470 (2006).

11. Ralph Peeples, Catherine Harris \& Thomas Metzloff, Settlement Has Many Faces: Physicians, Attorneys and Medical Malpractice, 41 J. HEALTH \& SOC. BEHAV. 333, 343-44 (2000). 
expertise. Clearly the disciplines of law and sociology have much to offer each other, particularly in the context of medical malpractice. A medical malpractice claim typically involves a challenge to the competency of a member of a learned profession (medicine). Thus, it raises the question of who should assess the merits of the claim: a fellow member of the profession, another physician, or an "outsider," such as a judge or a jury. This is the sort of conflict sociologists are trained to study. By contrast, a claim of medical malpractice is seen by lawyers as a tort, based on negligence. Torts and claims of negligence are the province of the law and the courts. By combining the perspectives of both disciplines, we can get sharper pictures of the litigation process, its problems, and potential solutions. However, until either social scientists or legal scholars gain a thorough understanding of the other field, there will be little fruitful cross-disciplinary analysis. Signs that legal scholars are embracing empirical studies are therefore very promising.

Identifying a theory of litigation that is accessible to both sociologists and lawyers is not easy. After all, almost everything written on how the litigation process functions takes a rules-based (civil procedure) perspective. This is an approach with which lawyers would be more comfortable than sociologists. One of the few theories that address the dynamics of litigation without reference to traditional legal rules is Galanter's seminal discussion of "repeat players." 12 Galanter argues that attorneys acting as repeat players have advantages in the legal system that others do not. These advantages include an understanding of legal rules, ready access to specialists who can provide expert testimony, more readily available information about cases, and lower start-up costs. Daniels and Martin have recently argued, on the basis of data from Wisconsin and Texas, that repeat players within the medical malpractice plaintiffs' bar do exist, and that these repeat players tend to do better than non-repeat players. ${ }^{13}$

Understanding the litigation process of medical malpractice has practical and political, as well as academic, implications. An ability to seek redress for a perceived medical injury is important, but medical malpractice litigation, by its nature, is very expensive. Repeat players may perform a useful function in identifying truly meritorious cases. Interest in medical malpractice reform tends to be cyclical. The level of interest among legislators, scholars, and medical professionals tends to rise dramatically after a crisis, real or perceived, in the availability and cost of malpractice insurance. ${ }^{14}$ In addition, questions relating to

12. Marc Galanter, Why the "Haves" Come out Ahead: Speculation on the Limits of Legal Change, 9 LAW \& SOC'Y REV. 95, 97-102 (1974).

13. Stephen Daniels \& Joanne Martin, Plaintiffs' Lawyers, Specialization, and Medical Malpractice, 59 VAND. L. REv. 1051, 1059-60 (2006).

14. See Ralph Peeples \& Catherine Harris, Learning To Crawl: The Use of Voluntary Caps on Damages in Medical Malpractice Litigation, 54 CATH. U. L. REV. 703, 704 (2005); William M. Sage, Understanding the First Malpractice Crisis of the 21st Century, in HEALTH LAW HANDBOOK 1-4 (Alice G. Gosfield ed., 2003); David M. Studdert, Michelle M. Mello \& Troyen A. Brennan, Medical Malpractice, 350 NEw ENG. J. MED. 283, 284-85 (2004). 
the resolution of medical malpractice claims point toward larger issues of health care reform. Although the incidence of medical error far exceeds the rate at which claims are made against physicians and hospitals, the sum of payments made in resolution of malpractice claims is substantial. ${ }^{15}$ For example, in 2006, almost 12,500 reports of payments on behalf of physicians were submitted to the National Practitioner Data Bank (NPDB). ${ }^{16}$ The mean payment was $\$ 308,817$, and the median payment was $\$ 175,000$; the total of payments reported on behalf of physicians was nearly $\$ 3.9$ billion. ${ }^{17}$ When the associated "transaction costs" of claims adjusting, expert opinions, and attorneys' fees are included, the cost of managing medical malpractice claims grows substantially. ${ }^{18}$

Lawyers play a critical role in the process of resolving medical malpractice claims. Understanding this role is a necessary condition for reforming the system. Certainly, lawyers are important because they represent both parties. The parties expect their lawyers to make recommendations regarding settlement offers and trial. Plaintiffs' lawyers also perform a screening function. A lawyer is not required to take a civil case. Because plaintiff's lawyers are customarily compensated on a contingency fee basis, ${ }^{19}$ the potential client must present a case that, in the lawyer's estimation, has some potential monetary value. Otherwise, the lawyer will collect no fee. For this reason, potential plaintiffs with weak cases may be unable to find representation. ${ }^{20}$ Defense counsel performs a similar, but distinct, screening function. Although defendants' counsel is usually paid on an hourly basis, the client's insurer expects an honest assessment of the likelihood of prevailing if the case goes to trial. Because the defense counsel wishes to receive future cases from the insurer, she has the incentive to assess the viability and value of a particular claim accurately. Thus, for both plaintiffs' and defense counsel, an ability to assess cases accurately is important. Being able to pick cases that are likely to result in settlement or award is a particular concern for plaintiff's counsel.

15. Patricia M. Danzon, Medical Malpractice 19-29 (1985); Paul Weiler et al., A Measure of Medical MalPractice 128-29 (1993). See generally Comm. ON Quality of HealthCare in Am., Inst. of Med., To Err Is Human: Building a Safer Health System 42-43 (Linda T. Kohn et al. eds., 2000) (summarizing a number of studies that estimate the costs of medical errors).

16. U.S. Dep't of Health \& Human Servs., National Practitioner Data Bank, http://www.npdbhipdb.hrsa.gov/publicdata.html (last visited Apr. 28, 2008) [hereinafter NPDB]. The NPDB was established by Congress in Title 4 of the Health Care Quality Improvement Act, Pub. L. No. 99 660,100 Stat. 3784 (1986) (codified at 42 U.S.C. $\$ 11101$ (2000)). The Act requires that any amount paid by an insurer on behalf of a physician must be reported to the NPDB. Id. Whether liability was ever established is not relevant. Thus, both judgments and monetary settlements must be reported.

17. NPDB, supra note 16.

18. Studdert, Mello \& Brennan, supra note 14, at 285-86.

19. Paul Weiler, Medical Malpractice on Trial 62 (1991).

20. See David A. Hyman \& Charles Silver, Medical Malpractice Litigation and Tort Reform: It's the Incentives, Stupid, 59 VAND. L. REV. 1085, 1102-03 (2006). 
Liability insurers also play a central role in medical malpractice disputes. In return for a premium, an insurer provides the insured physician with a defense lawyer and pays any indemnity resulting from settlement or trial, up to the limits of the policy. ${ }^{21}$ At the start of the medical malpractice litigation process, an individual patient, the patient's representative, or the patient's lawyer makes a claim. The claim can be simply a written demand for payment, or it can first appear as a summons and complaint, signaling that a lawsuit has been filed. One of the insurer's own staff, usually a claims adjuster, then makes an evaluation of the claim's merits. Medical records are obtained and customarily sent out for review by other physicians whose specialty is the same or similar to that of the insured physician. If the matter appears likely to result in litigation, or if a complaint has already been filed, the insurer retains defense counsel for the physician and arranges for expert witnesses. If the patient files a complaint, depositions of the plaintiff, treating physicians, defendant, and experts for both sides are scheduled and conducted. At any point in the process, either side may initiate settlement discussions. The settlement discussions typically focus on predicting the likely outcome if a trial were held, both as to verdict and as to damages. If the sides cannot settle, the case proceeds to trial.

In a previous article we argued that factors other than an assessment of liability, such as the perceived witness potential of the plaintiff and the defendant, as well as the reputation of the plaintiff's counsel, are frequently taken into account by the insurer in deciding whether to seek a settlement before trial. ${ }^{22}$ We have also argued that the insurer's decision to seek a settlement is crucialwhen an insurer makes an offer, any offer, the chances are very high that the case will settle. ${ }^{23}$ In this Article, we examine another factor, apart from liability: the experience and case-picking ability of plaintiff's counsel.

This Article is the result of an interdisciplinary effort in which data were collected from court records and other archival sources, supplemented by a limited number of questionnaires and interviews with attorneys (both defense and plaintiffs' counsel in the cases we studied). Building on the work of Galanter, we explore the question of whether the experience of opposing counsel affects medical malpractice case outcomes. We look at this question in the context of the case, including severity of alleged injury, whether there was a trial and, for a limited number of cases, insurers' and plaintiffs' counsel's assessment of liability.

In Part I of this Article, we survey the literature that addresses the predictors of outcome in medical malpractice cases. We note that the characteristics of

21. Different insurance companies insure physicians in different parts of the country. Although the process we describe here is based on our observations in North Carolina, we believe this process is typical for most professional liability insurers.

22. Harris, Peeples \& Metzloff, supra note 10.

23. Ralph Peeples, Catherine Harris \& Thomas Metzloff, The Process of Managing Medical Malpractice Cases: The Role of Standard of Care, 37 WAKE FOREST L. REV. 877 (2002). 
counsel are rarely considered. We argue that in order to understand the litigation process, the impact of lawyer competence and skill needs to be addressed.

Part II explains the steps in our statistical analysis. Our dependent variable is whether money is paid to the plaintiff. There are three categories of independent variables: relevant experience, case context, and insurers' assessment of liability. We begin with a bivariate analysis, move to a multivariate analysis, and finally, in order to understand the relationships among variables, do a series of crosstabulations, introducing an attorney effectiveness variable.

In Part III, we describe our sample and the variables we used to measure attorney effectiveness. In Part IV, we report our findings. We find that, consistent with our previous research, ${ }^{24}$ the insurer's assessment of liability as probable or uncertain predicts whether money is paid to the plaintiff. An in-depth look at the impact of attorney effectiveness and malpractice case experience reveals that more effective attorneys are more likely to settle and less likely to go to trial. If the defense and plaintiff's counsel agree about liability, and liability is probable or uncertain, the plaintiff is more likely to be paid. Finally, plaintiffs' lawyers who handled at least four malpractice cases and who were successful in obtaining money for their clients during the study period are more likely to agree with the insurer's assessment and their clients are more likely to be paid.

In Part V, we discuss our findings in the context of previous literature. In short, attorney experience and skill matter. In this small sample, the ability to pick cases (i.e., to assess them as the insurer does) is associated with effectiveness-experience and skill. We conclude with suggestions for future research and policy implications.

\section{Predictors of Outcome in Medical Malpractice Cases: Previous LITERATURE}

Does counsel make a difference for medical malpractice case outcomes? In other words, does it matter who the plaintiff's lawyer is and who the defendant's lawyer is? Not every observer thinks so. Some earlier work in the area of medical malpractice litigation suggests that the identity of the lawyers does not really matter. For example, Taragin et al. concluded that compensation for medical malpractice claims is closely associated with probable liability, as determined by peer (i.e., fellow-physician) review. ${ }^{25}$ Similarly, studies by Sloan and $\mathrm{Hsieh}^{26}$ and by Farber and White ${ }^{27}$ found a connection between negligence, as determined by

24. Harris, Peeples \& Metzloff, supra note 10.

25. Mark I. Taragin et al., The Influence of Standard of Care and Severity of Injury on the Resolution of Medical Malpractice Claims, 117 ANNALS INTERNAL MEd. 780 (1992).

26. Frank A. Sloan \& Chee Ruey Hsieh, Variability in Medical Malpractice Payments: Is the Compensation Fair?, 24 LAW \& SOC'Y REV. 997 (1990).

27. Henry S. Farber \& Michelle J. White, Medical Malpractice: An Empirical Examination of the Litigation Process, 22 RAND J. ECON. 199 (1991). 
physicians, and compensation. It follows that the central event in a rational system of compensation is the determination of medical fault by a panel of experts based upon a review of the relevant records. ${ }^{28}$ In this account the relative competence and skill of the lawyers for the plaintiff and defendant does not matter greatly, particularly if a schedule of compensation for specified injuries is used. $^{29}$ Members of the medical, not legal, profession make the key determination of medical fault. ${ }^{30}$ Still, the fit between fault and compensation has never been exact. ${ }^{31}$

Using a different model, Brennan et al. argue that compensation is connected to severity of injury, defined in terms of temporary or permanent disability-but not much else. ${ }^{32}$ Recent reviews of the published studies of medical malpractice have concluded that the findings of Brennan et al. are inconsistent with virtually every other study on the subject. ${ }^{33}$ Still, if Brennan et al. are correct that severity of injury is the crucial variable, the role of lawyers would not be critical to the outcome of the case. Thus, if medical liability, severity of injury, or some combination of the two adequately predicts payment, it seems that the dynamics of lawyer confrontation may not matter.

Even if negligence and medical liability predict payment, however, that would not mean lawyers have no role. First, even if negligence determines compensation, negligence may be determined by non-physicians (e.g., a lay jury), giving lawyers a role in the process. Second, even if liability predicts payment, liability is not always reducible to a simple yes or no question. Sometimes the key medical facts are subject to interpretation. Sometimes the appropriate course of treatment is a matter of professional debate. Sometimes different reviewers reach different conclusions, even when presented with identical information-whether the reviewers are physicians, insurers, lawyers, or laypersons. As a result, for better or worse, lawyers play a pivotal role in the determination of liability. Finally, there is an informational disparity with respect to "liability": The insurer will know more about potential liability than the plaintiff's attorney will. After all, the insurer may be able to get the unvarnished truth from the doctor, but the plaintiff probably cannot. Thus, for any given claim for compensation, the predictive value of a model based on liability is quite

28. Taragin et al., supra note 25 , at 783 .

29. See Catherine T. Harris, Ralph Peeples \& Thomas B. Metzloff, Who Are Those Guys? An Empirical Examination of Medical Malpractice Plaintiffs' Attorneys, 58 SMU L. REv. 225, 227 (2005).

30. To a substantial extent, this has long been the case. Most medical malpractice claims rely on the testimony of experts, who are invariably physicians and who typically practice in the same field. See DAN B. DoBBS, THE LAW OF TORTS $\S 246$, at 639 (2000).

31. Harris, Peeples \& Metzloff, supra note 10, at 470.

32. Troyen A. Brennan, Colin M. Sox \& Helen R. Burstin, Relation Between Negligent Adverse Events and the Outcomes of Medical-Malpractice Litigation, 335 NEW ENG. J. MED. 1963 (1996).

33. See infra note 35 . 
limited, at least from the plaintiff's point of view. This is especially true for claims where fault is neither clearly present nor unquestionably absent.

Severity of injury is different. Unlike liability, which represents a reasoned conclusion based on the facts presented, severity of injury is merely an objective attribute of a case. ${ }^{34}$ As a result, severity needs to be understood in context and considered in connection with other case attributes, taking into account the experience of opposing counsel. ${ }^{35}$

On the surface, the conclusions of Taragin et al., ${ }^{36}$ who see the crucial variable as assessment of liability, and Brennan et al., ${ }^{37}$ who argue that the crucial variable is severity of injury, seem inconsistent. Severity of injury, as identified by Brennan et al., bears no necessary connection to liability, as described by Taragin et al. We argue that both conclusions present an incomplete picture of the process of medical malpractice litigation, especially since there is evidence that physicians who have been sued do not necessarily agree that they were liable. ${ }^{38}$ One might speculate that doctors may not objectively assess their own potential liability.

Over the past several years, a consensus has emerged among academic observers that the medical malpractice system operates, overall, in a rational and predictable way. ${ }^{39}$ There is a clear connection between the quality of the case, expressed in terms of likely liability, and compensation. Despite this apparent rationality, some questions remain. The fit between quality and outcome is imperfect. Other factors, such as the expertise of counsel, need to be examined more closely.

As Heinz and Laumann observed almost thirty years ago, the profession of law is less studied and less understood than the profession of medicine. ${ }^{40}$ This pattern has not changed. While studies occasionally address issues of professional stratification ${ }^{41}$ and specialization, ${ }^{42}$ few studies have considered the

34. Frank A. Sloan et al., Suing for Medical Malpractice 22-24 (1993) (describing the National Association of Insurance Commissioners (NAIC) scale for severity of injury, which uses a nine-point scale classifying from (1) emotional only to (9) death).

35. See Hyman \& Silver, supra note 20, at 1094-1100; Philip G. Peters, Jr., What We Know About Malpractice Settlements, 92 IowA L. REV. 1783, 1803 (2007); see also Tom Baker, Reconsidering the Harvard Medical Practice Study Conclusions About the Validity of Medical Malpractice Claims, 33 J.L. MED. \& ETHICs 501, 502-06 (2005).

36. Taragin et al., supra note 25.

37. Brennan, Sox \& Burstin, supra note 32.

38. Peeples, Harris \& Metzloff, supra note 11, at 333.

39. See, e.g., Hyman \& Silver, supra note 20, at 1087; Peters, supra note 35, at 1831-32.

40. John P. Heinz \& Edward O. Laumann, The Legal Profession: Client Interests, Professional Roles, and Social Hierarchies, 76 MICH. L. REV. 1111, 1111-12 (1978).

41. Jerome E. Carlin, Lawyers on Their OWN: The Solo Practitioner in an Urban SetTing (1994); H. Laurence Ross, SeTtled out of Court: THE SocIal Process of INSURANCE Claims Adjustment, 73-76 (1970); Erwin O. Smigel, The Wall Street Lawyer (1969); Heinz \& Laumann, supra note 40; Jack Ladinsky, Careers of Lawyers, Law Practice and Legal Institutions, 28 AM. Soc. REv. 47 (1963); Rebecca Sandefur, Work and Honor in the Law: Prestige 
relative importance of competence and skill in determining case outcomes. Given the obvious difficulties in measuring competence and skill, and in determining case outcomes with precision, this is not surprising. What evidence exists on the subject suggests that case evaluation and negotiation skills make a large difference in case outcomes. ${ }^{43}$ We previously authored one of the few empirical studies focusing on the impact of relevant experience. ${ }^{44}$ We found that "seasoned plaintiffs' attorneys," meaning those who had handled at least four medical malpractice cases during the study period, who had conducted at least one malpractice trial during this period, and who had attended law school in-state, were more successful than other plaintiffs' attorneys in obtaining money for their clients. $^{45}$

In their study of medical malpractice lawsuits in Florida, Sloan et al. suggested that the skill and competence of the lawyer for the plaintiff might be a factor in determining the outcome of specific cases. ${ }^{46}$ Sloan et al. concluded that in terms of monetary recovery, claimants represented by "specialist" attorneys fared better than claimants represented by non-specialist attorneys. ${ }^{47}$ They further observed that the relative importance of who the lawyers are in a particular medical malpractice case had never been the subject of empirical study. ${ }^{48}$ Sloan et al.'s measurement of the impact of specialist attorneys on case outcomes represented a pioneering effort. The study, however, considered only the influence of plaintiff's counsel on case outcomes and payment, while the impact of defense counsel was largely ignored. In addition, the study used a number of different criteria, both objective and subjective, for determining specialist status. Sloan et al. defined "specialist" to include: attorneys who handled four or more medical malpractice cases, whether in or out of their sample, as well as their partners and associate attorneys; lawyers listed as experts in tort law in The Best Lawyers in America; members of the Inner Circle of Advocates; and attorneys who identified themselves as medical malpractice specialists in the MartindaleHubbell National Directory of Lawyers. ${ }^{49}$ Thus, while perhaps more widely studied than most other areas of law, even in the field of medical malpractice one finds relatively little objective data on the topic of lawyer competence and skill.

and the Division of Lawyers' Labor, 66 AM. SOC. REV. 382 (2001).

42. Ross, supra note 41; Edward O. Laumann et al., Washington Lawyers and Others: The Structure of Washington Representation, 37 STAN. L. REV. 465 (1985).

43. Gerald R. Williams, Legal Negotiation \& Settlement 5-7 (1983); see also Kritzer, supra note 1 , at 54-55.

44. Harris, Peeples \& Metzloff, supra note 29.

45. Id. at 245-47. See generally Daniels \& Martin, supra note 13 (discussing repeat players and specialists in malpractice cases).

46. SlOAN ET AL., supra note 34.

47. Id. at 196.

48. Id. at 164 ("The effects of plaintiff lawyer competence and one-time versus repeat attorney players ... have not been examined at all.").

49. Id. at 170. 
Our approach in this Article adds attorney experience to those variables that have traditionally been argued to predict payment in medical malpractice cases, such as the severity of the alleged injury ${ }^{50}$ and assessment of liability. ${ }^{51}$ We also look at the relationship among attorney experience, the ability to pick cases, and case outcome.

\section{APPROACH TO ANALYSIS}

We focus our analysis on a single question: whether the plaintiff received any money. It may appear reductive to simply examine whether the plaintiff received an award without considering the size of this award. We rely on this dichotomous variable for two reasons. First, any payment, regardless of amount, triggers the reporting requirements of the NPDB. ${ }^{52}$ One must submit a record identifying the physician on whose behalf the payment was made, without regard to the merits of the case, and without regard to whether the payment was made pursuant to a settlement or a verdict. Therefore, the simple fact of payment matters. Second, in practice, many settlement amounts are kept confidential. While it was sometimes possible to learn the specific amount paid, we were unable to obtain this information for all cases.

We begin with a bivariate analysis, looking at whether money was paid to the plaintiff by examining: relevant experience variables, specifically malpractice case experience and general experience; case context variables, specifically severity of the alleged injury and whether a trial occurred; and the insurer's assessment of liability. Utilizing binary logistic regression, we look at what variables predict case outcome, in terms of whether money is paid. For these analyses we enter the three clusters of variables discussed above into the model. First, we enter experience variables, including general experience and medical malpractice case experience-"repeat playing." Second, we add case context characteristics: severity of injury and whether there was a trial. Third, for a limited number of cases for which the data were available $(n=72)$, we add the insurers' assessment of liability to the model.

To understand the circumstances under which money is paid, in the cases in which data for both defense and plaintiffs' counsel were available $(n=52)$, we look at the extent to which plaintiffs' counsel's assessment agreed with that of the insurer. We introduce a variable that measures the effectiveness of plaintiffs' counsel defined in terms of having handled at least four cases during the study period and obtained payment in at least half of them. We look at several questions: Are more effective attorneys more likely to assess liability in a way that matches the assessment of the insurer? How does this agreement, or lack thereof, affect case outcome? Does it affect the occurrence of a trial? Insurers act

50. Brennan, Sox \& Burstin, supra note 32, at 1966.

51. Taragin et al., supra note 25 , at $781,783$.

52. See supra note 16 and accompanying text. 
rationally, settling cases when they evaluate liability as probable and not settling when liability is seen as unlikely. ${ }^{53}$ Finally, we look at the extent to which a combination of agreement with the insurer assessment of liability and medical malpractice case experience affects the payment of money to the plaintiff.

It should be noted that although statistical significance is set at $p<0.05$, results that approach but do not reach significance are also reported in the text, in the case of some cross-tabulations, and within the tables in multivariate analyses. This is done to contribute to a greater understanding of the relative impact of the variables.

\section{METHODS}

In our first analysis, the dependent variable is case outcome (whether money was paid in a given medical malpractice case). Our independent variables include time since admitted to practice (general experience), the number of medical malpractice cases handled during the study period (case experience), whether the case went to trial, severity of the alleged injury and, (in a limited number of cases) assessment of liability by defense and plaintiff's counsel. In our next analyses, we add counsel effectiveness as an independent variable, looking at its impact on assessment of liability and the occurrence of a trial in the case.

\section{A. Sample}

Our study is based on the collected data from 348 medical malpractice lawsuits filed in North Carolina between 1992 and 1995. While we do not suggest that our data set is a random sample of a complete population, given the fact that there is no data set of medical malpractice cases in North Carolina, we believe that it is a logical sample for this type of analysis. We determined the final outcomes of these cases using a combination of techniques, including a review of the court files for each case and the use of archival data on attorneys. ${ }^{54}$ For each case, we identified the counsel for the plaintiff and the counsel for the defendant; all counsel were licensed in North Carolina. Archival sources provided information about the number of years since the attorney was admitted to practice. Court files provided information about the number of medical malpractice cases handled during the study period as well as the outcomes of these cases. Matching our data sources resulted in an upper limit of 306 usable cases. For a limited number of cases $(n=72)$ we have a combination of interview and questionnaire data that utilizes the defense attorneys' evaluation of liability

53. Harris, Peeples \& Metzloff, supra note 10, at 468-70; Peeples, Harris \& Metzloff, supra note 23, at 893-94.

54. We relied on a number of sources to obtain this information, primarily directories published by the North Carolina Bar Association and Martindale-Hubbell. 
as a proxy for insurers' assessment of liability. ${ }^{55} \mathrm{We}$ also collected data on plaintiffs' assessment of liability. Matching the data on defense counsel's assessment with that of plaintiffs' counsel resulted in fifty-two usable cases. In all our analyses we used data where they were available. There were missing values for some variables, as is frequently the case with data sets. As a result, the numbers of cases in different analyses varied.

Given that there is no malpractice case database in North Carolina from which a sample could be randomly selected, we focused on durable cases. Following the notion of the dispute pyramid, ${ }^{56}$ durable cases, or those that had progressed at least beyond the initial stages of complaint by the plaintiff and answer by the defendant, seemed to be the most appropriate for looking at litigation as a process. Our sample consists of closed cases that progressed far enough to be ordered to mediation by the trial court, under the auspices of a pilot program mandated by the North Carolina General Assembly in 1991. Thus a type of control for case durability is provided since they moved farther along through the dispute resolution pyramid. This means that frivolous cases are excluded from the analysis, enabling us to more clearly focus on the actual litigation process. On the other hand, we recognize that this is not a random sample and that these cases may have characteristics that differ from cases not ordered to mediation. It should be noted that although only eighteen of the state's one hundred counties were a part of the pilot program, the pilot counties included five of the six most populous cities in the state (Charlotte, Raleigh, Greensboro, Winston-Salem, and High Point). In addition, in the eighteen pilot counties, all filed civil cases were ordered to mediation. Thus, we believe that we have collected the vast majority of all medical malpractice cases filed in the pilot counties during the study period. (Today, virtually all medical malpractice cases filed in North Carolina are ordered to mediation.) In short, we believe that the cases we analyze were representative of medical malpractice cases generally in North Carolina during the study period, since the counties that were selected by the state legislature were picked to provide a diverse group of counties, representing all geographic regions and including both sparsely and densely populated counties. Given the nature of the selection process, we also believe that this state-specific data set may be generalized to other parts of the country.

While our sample is limited to North Carolina and includes only eighteen of one hundred counties, the results of our study could inform national discussion of medical malpractice litigation because there are few studies that combine court data, insurance data, and questionnaires. Use of multiple data sources provides a more complete picture of the litigation process.

55. The defense attorneys' evaluation is based on that of the insurer, which is in turn based on that of the outside physician reviewers. Peeples, Harris \& Metzloff, supra note 23, at 884-85, 897.

56. Miller \& Sarat, supra note 5, at 544-46. 


\section{B. Dependent Variable: Case Outcome}

As a result of our examination of court records, attorney questionnaires, and attorney interviews, we were able to determine for most cases $(296 / 348,85.1 \%)$ if money had been paid, whether in settlement of the case or as a result of a favorable jury verdict. Overall, payment occurred in $50.4 \%$ of cases. It should be kept in mind, however, that these were durable cases. ${ }^{57}$ Although it was possible to determine whether money was paid, as we mentioned earlier, it was seldom possible to determine the actual amount paid. The settlement terms of medical malpractice lawsuits typically take the form of a private contract between the parties, and thus are not subject to public scrutiny. ${ }^{58} \mathrm{~A}$ common condition of settlement is a pledge extracted from the plaintiff and the plaintiff's counsel not to disclose the amount paid in settlement of the lawsuit. ${ }^{59}$ Thus, although we were able to obtain actual settlement amounts for some cases, the insufficient number of such cases precluded utilizing settlement amounts as a dependent variable. Instead, we created a binary variable in which "money paid" was coded as " 1 " and money not paid was coded as " 0 ." This binary approach regarding payment of money places the payment rate of $50.4 \%$ in context. The payment of several thousand dollars in a case might be considered a statistical "win" for the plaintiff, but it is unlikely that either the plaintiff or the plaintiff's counsel would see it that way. Use of "money paid" as the dependent variable has the advantage of acting as a control, since regardless of the amount paid there may be negative consequences for the physician. No matter what amount of money was paid, the defendant-physician will become part of the National Practitioner Data Bank. ${ }^{60}$ This may result in negative professional consequences, since hospitals, HMOs, and PPOs have access to this data.

\section{Independent Variables}

In our first analyses there are three categories of independent variables: attorney experience variables, which included time since admitted to practice (general experience) and number of medical malpractice cases handled (case experience); case context variables (severity of alleged injury and the occurrence of a trial); and insurers' assessment of liability (probable, uncertain, or unlikely). In the second set of analyses, effectiveness of plaintiff's counsel is the independent variable. The variables and their coding are presented in Table 1.

57. Imposing a filter on medical malpractice cases, such as a requirement that an order to mediate the case has been issued, has the effect of reducing the number of cases in the study that were abandoned early in the process by plaintiffs, for whatever reason.

58. Harris, Peeples \& Metzloff, supra note 29, at 233.

59. See id.

60. See supra note 16. 


\begin{tabular}{|c|c|c|}
\hline Variables & Definition/Comment & Coding \\
\hline \multicolumn{3}{|l|}{ Dependent variables } \\
\hline Money paid & $\begin{array}{l}\text { Case in which money was paid to the } \\
\text { plaintiff. }\end{array}$ & $0=$ Money not paid $\quad 1=$ Money paid \\
\hline $\begin{array}{l}\text { Performance: } \\
\text { Attorney } \\
\text { effectiveness } \\
\text { plaintiff's counsel }\end{array}$ & $\begin{array}{l}\text { Plaintiff's counsel handled at least four } \\
\text { cases and won at least half of them. }\end{array}$ & l=More Effective \\
\hline \multicolumn{3}{|l|}{$\begin{array}{l}\text { Independent } \\
\text { variables }\end{array}$} \\
\hline \multicolumn{3}{|l|}{$\begin{array}{l}\text { Experience } \\
\text { Variables }\end{array}$} \\
\hline $\begin{array}{l}\text { Years since } \\
\text { admitted to } \\
\text { practice }\end{array}$ & $\begin{array}{l}\text { Archival sources were used to determine } \\
\text { the number of years in practice. These } \\
\text { interval level data were utilized. }\end{array}$ & $\begin{array}{l}\text { Defense Counsel: range }=1-46, \text { median }=20 \\
\text { Plaintiffs' Counsel: range }=1-47 \text {, median }=18\end{array}$ \\
\hline $\begin{array}{l}\text { Malpractice case } \\
\text { experience }\end{array}$ & $\begin{array}{l}\text { Number of medical malpractice cases } \\
\text { handled as collected from the court files } \\
\text { during the study period. }\end{array}$ & $\begin{array}{l}\text { Defense counsel: range }=1-29, \text { median }=9 \\
\text { Plaintiffs' Counsel: range }=1-19, \text { median }=2\end{array}$ \\
\hline \multicolumn{3}{|l|}{$\begin{array}{l}\text { Case context } \\
\text { variables }\end{array}$} \\
\hline $\begin{array}{l}\text { Occurrence of a } \\
\text { trial }\end{array}$ & Whether a trial occurred in this case. & $\mathrm{I}=$ Yes $0=\mathrm{No}$ \\
\hline $\begin{array}{l}\text { Trial experience: } \\
\text { Defense and } \\
\text { plaintiff's counsel }\end{array}$ & $\begin{array}{l}\text { If the court records indicated that the } \\
\text { attorney had tried a medical malpractice } \\
\text { case. }\end{array}$ & $1=$ Yes $\quad 0=$ No \\
\hline $\begin{array}{l}\text { Severity of } \\
\text { alleged injury }\end{array}$ & $\begin{array}{l}\text { Less severe injuries included emotional } \\
\text { only, insignificant injury, minor } \\
\text { temporary disability and major } \\
\text { temporary disability. }\end{array}$ & $1=$ More severe $0=$ Less Severe \\
\hline $\begin{array}{l}\text { Assessment of } \\
\text { liability }\end{array}$ & Defense counsel's assessment. & $\begin{array}{l}\text { Two dummy variables } \\
1=\text { liability probable } \\
1=\text { liability uncertain } \\
0=\text { liability unlikely, reference category }\end{array}$ \\
\hline
\end{tabular}

In our tabular analyses, utilizing Chi-square and appropriate measures of association, interval level variables are recoded to ordinal level variables, appropriate to this statistic (Tables 2,7 , and 8 ). In our tables with very small numbers (Tables 7 and 8 ) Fisher's exact test was used. It should be noted that in some tables, also with small samples (Tables 4-6), comparisons using percentages are more meaningful. Interval level and dummy variables are appropriate as independent variables for binary logistic regression in Table 3. 


\section{Attorney Experience Variables}

\section{a. General Experience}

Data are available from attorney directories on the year attorneys were first admitted to practice and the law school from which they graduated. Using information from these directories, we computed the years of general experience of the attorneys. For our bivariate analysis we recoded years of experience into greater or less than ten years, mindful of the time it traditionally takes to become a partner in a law firm. Becoming a partner is used as an indicator of sustained successful experience in a law firm.

\section{b. Case Experience: Number of Medical Malpractice Cases Handled by Defense and Plaintiffs' Counsel}

We calculated the number of medical malpractice cases each attorney handled during the study period. For cases with more than one defense counsel (due to the involvement of more than one defendant) we determined, based on a review of the court file, the identity of the primary defendant and thus the identity of the primary defense counsel. Only the primary defense counsel was credited with case experience for handling that case. We also looked at the severity of the alleged injury and whether there was a trial.

Experience, particularly specific experience in medical malpractice cases, serves as a useful indicator of competence and skill for several reasons. First, medical malpractice litigation is largely a specialty practice for lawyers, especially on the defense side. Second, simple market principles seem to be at work in this area. Defense counsel for physicians, and often for hospitals, are chosen by the malpractice insurance carrier. Insurers understandably used, and continue to use, attorneys who have demonstrated skill in defending medical malpractice cases. On the plaintiffs' side, market principles also seem to be at work. Plaintiffs' attorneys are compensated on a contingent fee basis. Thus, plaintiffs' counsel receives compensation only if the case results in a payment to the plaintiff. Plaintiffs' attorneys who have handled a substantial number of medical malpractice cases have likely demonstrated their skill in this complex and technical field. ${ }^{61}$ The costs of preparing a medical malpractice case are high enough, both in terms of time and money, to deter casual or occasional players. ${ }^{62}$

We measured malpractice case experience in terms of the number of medical

61. Harris, Peeples \& Metzloff, supra note 29, at 247-48.

62. See, e.g., Daniels \& Martin, supra note 13, at 1060-66. 
malpractice cases handled, apart from the general experience as a practicing lawyer. Because medical malpractice litigation is a specialty practice, we chose this approach. Attorneys for both plaintiffs and defendants tend to specialize in medical malpractice and to devote a substantial portion of their practice to this area. We defined malpractice case experience in terms of the actual number of cases handled during the study period. For our bivariate analysis we recoded this variable into two categories: four or more cases and less than four, as an indicator of the attorney handling an average of at least one case a year during the study period. Although this approach does not adjust for lengthier or more difficult cases, it does reflect the fact that market forces are at work since more cases may flow to attorneys who are perceived to be "better."

Of course, many experienced lawyers handle more than one medical malpractice case per year. This is reflected in our data. Our study was limited to only a portion of North Carolina during the study period; malpractice cases that were not filed in one of the pilot counties were not included in our study. One or more of the attorneys in our study may have handled cases in other counties.

\section{Case Context Variables}

\section{a. Severity of Alleged Injury}

Not every malpractice case is the same. Some cases involve very serious injuries, while others involve less significant harm. The dynamics of resolution for cases involving a very severe injury may differ from those cases involving only a modest or temporary injury. Indeed, previous work in this field has suggested as much. ${ }^{64}$

We identified nine different levels of severity of injury, ranging from emotional injury alone to death. This is consistent with the approach of Sloan and Hsieh who obtained these categories from the National Association of Insurance Commissioners and the General Accounting Office. ${ }^{65}$ A binary variable was created in which " 1 " indicated more severe injuries and " 0 " less severe injuries. More severe injuries included minor permanent partial disability, major permanent partial disability, major permanent total disability, grave permanent total disability, and death. Less severe injuries included emotional injury only, insignificant injury, minor temporary disability and major temporary disability. We argue that there is a difference between injuries that are temporary and those that are permanent, with the latter being more serious.

63. Referrals from other lawyers to plaintiffs' lawyers who specialize in medical malpractice are common. See id. at 1067.

64. Brennan, Sox \& Burstin, supra note 32, at 1966; Sloan \& Hsieh, supra note 26, at 1007-08.

65. Sloan \& Hsieh, supra note 26, at 1004. 


\section{b. Occurrence of a Trial}

The occurrence of a trial may be associated with certain characteristics of both the lawyers and the cases. Whether counsel for the plaintiff or the defendant had medical malpractice trial experience in a given case was determined by the court records. A binary variable for each case was created, indicating whether or not a trial occurred. The occurrence of a trial was coded as "l" and the nonoccurrence of a trial was coded as " 0 ." Trial experience could be seen as an indicator of a willingness not to back down in the face of an uncertain outcome. ${ }^{66}$ Note that the consequences of going to trial differ substantially for defense and plaintiff's counsel. Plaintiff's counsel risk everything since they are compensated on a contingency fee basis. Defense counsel will receive their fee regardless of case outcome. This variable reveals plaintiff's counsel's judgment in deciding to go to trial, although the occurrence of a trial is a case characteristic. Alternatively, a trial could indicate either efficiency or lack of efficiency in settling cases, depending on the nature of the case and the skill of the attorney. There is evidence that if the insurer thinks liability is probable, settlement will occur. $^{67}$

\section{Assessment of Liability}

Using questionnaire and interview data collected from counsel to the defendant and to the plaintiff, we were able to collect data on assessment of liability in a limited number of cases. Attorneys were asked to evaluate liability as probable, uncertain, or unlikely. ${ }^{68}$ These evaluations were made after the case was closed. Defense counsel's evaluations were used as proxies for the insurers' evaluations, since, as noted above, defense counsel work for the insurer and the insurer, with the help of physician reviewers, ultimately evaluates the liability. These reviewers are usually paid consultants in a given malpractice case. ${ }^{69}$ We created a design variable with "unlikely liability" as the reference category since we focus on the case outcome of money being paid to the plaintiff. Thus we created two dummy variables: probable liability was coded "1" and not probable liability was coded " 0 "; uncertain liability was coded " 1 " and not uncertain liability was coded " 0 ."

66. Galanter, supra note 12, at 98-99; Harris, Peeples \& Metzloff, supra note 29, at 246.

67. Peeples, Harris \& Metzloff, supra note 23 , at $886-87$.

68. Attorneys were asked, "which of the following best describes your view of the issue of liability in this case." Choices were that 1) "liability as to at least one of the defendants was probable," 2) "liability was uncertain (a 'toss-up' type of case)," and 3) "liability was questionable or unlikely to be proven."

69. Peeples, Harris \& Metzloff, supra note 23, at 884-85. 


\section{Performance Measure: Effectiveness of Plaintiffs' Counsel}

To be considered effective, plaintiffs' counsel must have handled on average at least one medical malpractice case a year (so all effective counsel were also case-experienced counsel, as defined above) and have obtained money in at least half of those cases. If a plaintiff's counsel had at least four cases and had been paid money in at least half of them, his or her record was categorized as "more effective" (coded " 1 "). If counsel either did not have four cases or was not paid money in at least half the cases, counsel was categorized as "less effective" (coded " 0 "). A percentage of "wins" is useful since winning a medical malpractice case is difficult. ${ }^{70}$

The characteristics for effective defense counsel mirror those of plaintiff's counsel, having at least four cases during the study period and having money paid in no more than half of them. Our focus is on plaintiff's counsel's effectiveness, as insurers select their counsel on the basis of their demonstrated skill. While reputation and past outcomes count for plaintiff's counsel, the information is not always readily available to prospective plaintiffs, who must make decisions based on often incomplete information.

\section{FINDINGS}

The median number of years in practice for all defense attorneys for whom data were available ( $n=323)$ was twenty years. For plaintiffs' counsel $(n=307)$, it was eighteen years. Data on both number of medical malpractice cases handled and whether money was paid were available for most cases $(n=348)$. The median number of cases handled by defense counsel was seven, while the median was two for plaintiffs' counsel. In terms of general experience, $83.9 \%$ of defense counsel had at least ten years experience compared to $70.1 \%$ of plaintiffs' counsel. Over $76 \%$ of defense counsel had handled at least four cases compared to $39.7 \%$ of plaintiffs' counsel. In terms of level of effectiveness, $37.7 \%$ of defense counsel were more effective compared to $17.5 \%$ of plaintiffs' counsel. Over $19 \%$ of the more effective defense counsel had been involved in a trial compared to $22.2 \%$ of the more effective plaintiffs' counsel. A comparison of less effective plaintiffs' counsel who did not obtain money for their clients with those who had less than four cases shows little difference between the two. Those who had handled less than four cases lost $53.7 \%$ of the time and those who were less effective lost $53.5 \%$ of the time.

70. Philip G. Peters, Jr., Doctors and Juries, 105 MICH. L. REV. 1453, 1453-60 (2007). 
Over $71 \%$ of the cases involved more severe injuries, with $21.6 \%$ of all cases involving a death. Over $16 \%$ of all cases went to trial. Cases that went to trial did not differ significantly $(p=0.210)$ from those that did not by severity of alleged injury. Over $20 \%$ of more severe cases went to trial compared to $14.3 \%$ of cases with less severe injuries.

\section{A. What Predicts Whether Money Will Be Paid to the Plaintiff?}

Bivariate analyses of the impact of relevant experience variables, case context variables, and assessment of liability on the payment of money to the plaintiff are presented in Table 2. Interval level variables (years in practice and number of medical malpractice cases) were recoded, collapsing interval level variables into meaningful categories, the appropriate level of measurement for the analysis. Chi-square and appropriate measures of association were utilized in indicating whether there was a statistically significant difference in whether money was paid to the plaintiff by the independent variables. Significance levels that are just outside our level of significance are reported in the text. All significance levels are reported in Table 2, whether or not they were statistically significant. In terms of recoded relevant experience variables, general experience does not matter for either plaintiffs' or defense counsel. Medical malpractice case experience matters somewhat for plaintiffs' counsel, though the difference only approaches statistical significance. Medical malpractice case experience did not matter for defense counsel, keeping in mind that defense counsel are selected by the insurer and are almost always experienced. ${ }^{71}$ Recall that $76 \%$ of defense counsel had handled at least four cases compared to only $39.7 \%$ of plaintiffs' counsel. In terms of specific medical malpractice experience for plaintiffs' counsel, when counsel had handled four or more cases during the study period, money was paid in $57.1 \%$ of cases compared to $46.3 \%$ of cases in which counsel had handled less than four cases $(p=0.07$, Phi $=0.106)$.

Analyzing the impact of case characteristics, severity of the alleged injury mattered in terms of a comparison of the percentages. In cases with more severe injuries, money was paid in $53.6 \%$ of the cases, compared to $44 \%$ of cases with less severe injuries. If a trial occurred, money was less likely to be paid. When a case went to trial, there was an award in $26.8 \%$ of the cases, compared with a settlement in $56.4 \%$ of all cases that did not go to trial $(p<0.001$, Phi=-0.236).

Insurer's assessment of liability also had an effect. Money was paid in $78 \%$ of cases that were evaluated as having probable liability, in $73.7 \%$ of cases in which liability was assessed as uncertain, and in $33.3 \%$ of cases in which liability was viewed at unlikely $(p<0.001$, Phi $=0.423)$.

Our multivariate analysis utilizes binary logistical regression, appropriate to the binary dependent variable, "money paid to the plaintiff" yes (coded "1") or

71. Peeples, Harris \& Metzloff, supra note 23, at 880. 
no (coded " 0 "). In this analysis we evaluate the impact of each of the independent variables, controlling for the others, on the outcome of money being paid to the plaintiff. These results are presented in Table 3.

In Model 1, using only experience variables, defense counsel's general experience had some impact on money not being paid $(p=0.14)$, though outside statistical significance. On the other side of the dispute, malpractice case experience apparently was predictive of payment $(p=0.06)$ for plaintiff's counsel.

TABLE 2.

Money Paid to the Plaintiff and Relevant Attorney Experience, Case Context Variables and Insurers' Assessment of Liability

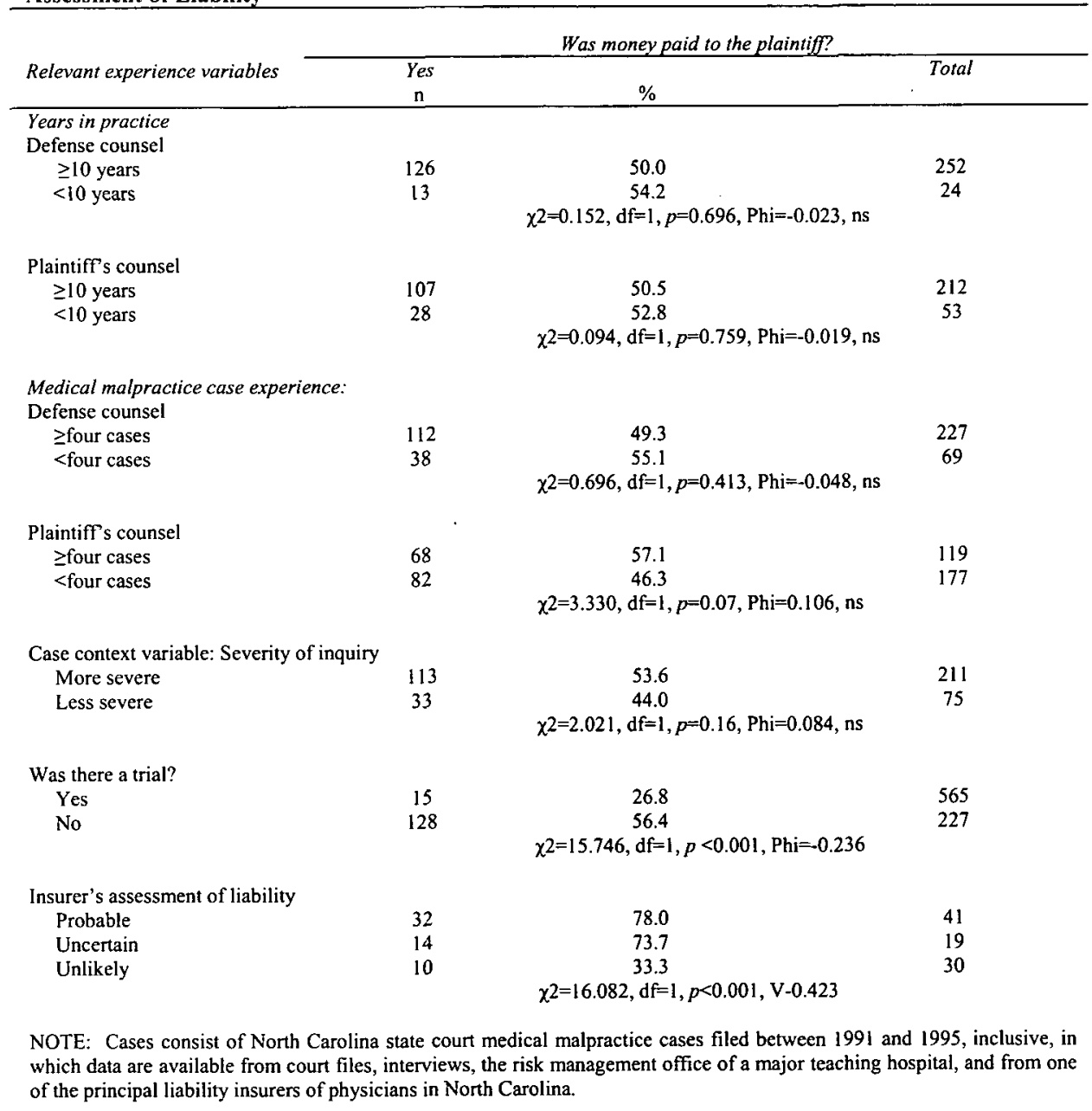


T.BLE. 3.

Logistic tonalycis for. Mosey Paid to the Plaintif

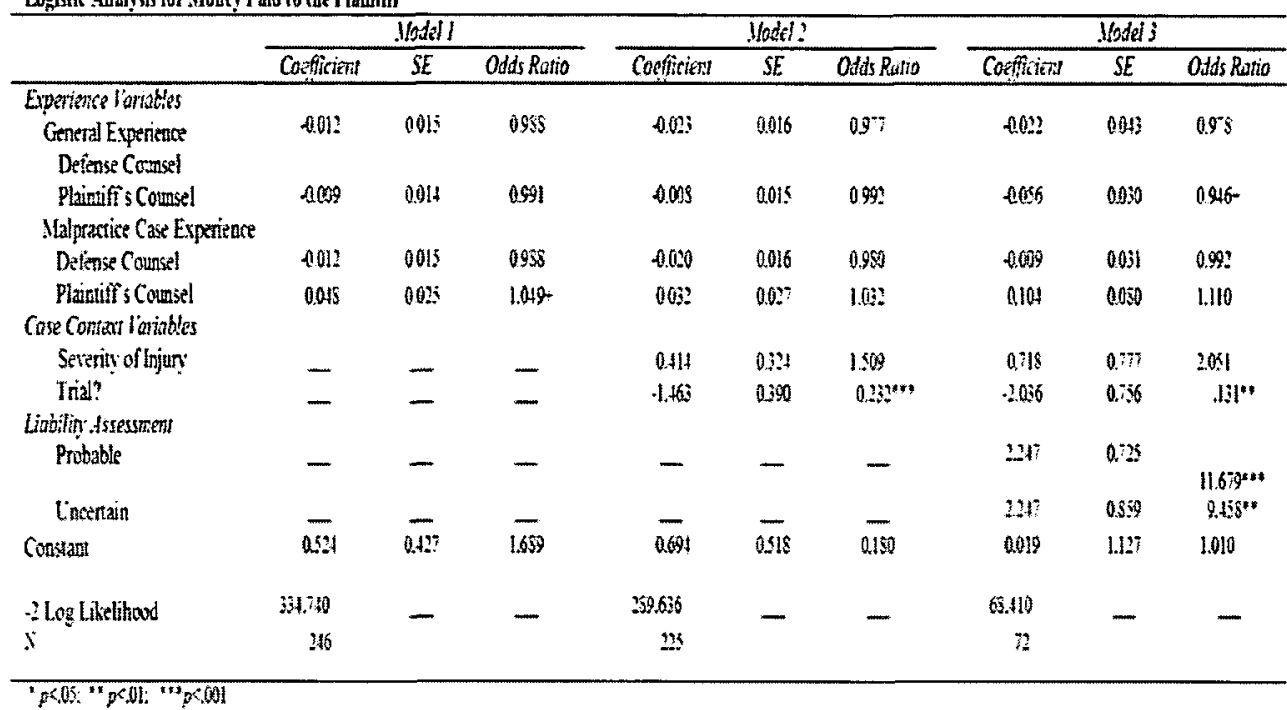

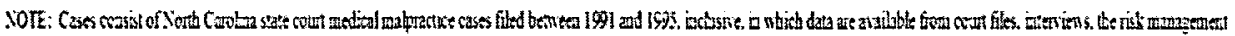

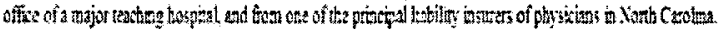

When case context variables are added to the model (Model 2), the negative coefficient indicates that if a trial occurred, this event was a significant predictor of money not being paid to the plaintiff $(p<0.001)$. The general experience of the defense counsel apparently continues to influence whether money is paid $(p=0.14)$. Severity of the alleged injury was not predictive of money being paid to the plaintiff.

In Model 3, the full model, for a limited number of cases for which the data were available $(n=72)$, the insurer's assessment of liability was added. The fact of a trial in the case continued to be a significant predictor of money not being paid $(p<0.01)$. An assessment of liability as either probable or uncertain was predictive of money being paid to the plaintiff $(p<0.001$ and $p<0.01$ respectively), as shown by the positive coefficients. The $-2 \log$ likelihood steadily diminished from Model 1 to Model 3, indicating that the additional variables contributed to the explanatory power of the model.

Our multivariate analysis indicates that, while plaintiffs' counsel's malpractice experience has an impact on the payment of money, further analysis of the process is needed. To continue the investigation, we look at the 
effectiveness of the plaintiff's counsel. Are more effective attorneys better at case-picking? In other words, are they better at evaluating liability in a given case in a way that agrees with the insurer's private assessment? If so, the attorney for the plaintiff would be in a better position to settle and avoid a trial. These analyses are based on defense counsel's assessment of liability (as proxy for the insurer), as well as a subset of plaintiffs' attorneys, who offered their assessment of liability in closed cases. These data are suggestive but must be viewed with caution because of small numbers. Some analyses only utilize percentages because of this limitation. Our findings are presented below.

\section{B. The Effectiveness of Plaintiffs' Counsel and Case-Picking}

Since the evaluations of the insurer drive case outcome ${ }^{72}$ we compare assessments of plaintiffs' counsel with those of defense counsel, whose evaluations are a proxy for that of the insurer. While data on assessment of liability are limited to fifty-two cases, these cases nonetheless allow us a detailed look at the dynamics of case settlement involving those variables that are shown to be important in both bivariate and multivariate analyses.

Even after the case closed it is interesting to note that plaintiffs' and defense counsel did not always agree on the assessment of liability (Table 4). Of the twenty-six cases that were evaluated by the defense as having probable liability, nineteen $(73.1 \%)$ of these cases were so evaluated by plaintiffs' counsel. There were twelve cases assessed by defense counsel as having uncertain liability but only two (16.7\%) of plaintiffs' counsel agreed. Finally, there were fourteen cases evaluated by defense counsel as having unlikely liability. Plaintiffs' counsel evaluated eight (57.1\%) of these cases as having probable liability. Although statistics are not reported because of small numbers and logical issues, it should be noted that the patterns of disagreement are surprising, given the fact that the cases were closed when the attorneys were asked their opinions regarding liability.

72. Peeples, Harris \& Metzloff, supra note 23 , at $880,887$. 
TABLE 4.

Defense and Plaintiffs' Counsel's Assessment of Liability: Percentage of Agreement

\begin{tabular}{|c|c|c|c|c|c|c|}
\hline \multirow{3}{*}{$\begin{array}{l}\text { Plaintiffs' counsel's } \\
\text { assessment }\end{array}$} & \multicolumn{6}{|c|}{$\begin{array}{l}\text { Defense counsel's assessment } \\
n=52\end{array}$} \\
\hline & \multicolumn{2}{|c|}{ Probable } & \multicolumn{2}{|c|}{ Unceriain } & \multicolumn{2}{|c|}{ Unlikely } \\
\hline & $n$ & $\%$ & $n$ & $\%$ & $n$ & $\%$ \\
\hline Probable & 19 & 73.1 & 9 & 75.0 & 8 & 57.1 \\
\hline Uncertain & 6 & 23.1 & 2 & 16.7 & 3 & 21.4 \\
\hline Unlikely & 1 & 3.8 & 1 & 8.3 & 3 & 21.4 \\
\hline
\end{tabular}

NOTE: Cases consist of North Carolina state court medical malpractice cases filed between 1991 and 1995, inclusive, in which data are available from court files, interviews, the risk management office of a major teaching hospital, and from one of the principal liability insurers of physicians in North Carolina.

Table 5 examines agreement between counsel's assessment of liability, controlling for attorney effectiveness. The table reveals that there is a greater likelihood that more effective attorneys are more likely to agree with the assessment of the insurer. This analysis reveals that in the nine cases handled by more effective plaintiffs' counsel, in six of nine $(66.6 \%)$ there was agreement with the assessment of defense counsel that liability was probable. In the two cases that the defense counsel evaluated as having uncertain liability, and in the case evaluated as having unlikely liability, the more effective plaintiffs' attorneys also saw these cases as having probable liability. The pattern, however, varied with less effective plaintiffs' counsel. While thirteen $(65 \%)$ of less effective counsel agreed with defense counsel about cases with probable liability, it is interesting to note that seven $(53.8 \%)$ of less effective plaintiffs' counsel evaluated cases assessed by the insurer as having unlikely liability as having probable liability.

TABLE 5.

Defense and Plaintiffs' Counsel's Assessment of Liability: Percentages of Agreement for More and Less Effective Plaintiffs' Counsel

\begin{tabular}{|c|c|c|c|c|c|c|c|c|c|c|c|c|}
\hline \multirow{4}{*}{$\begin{array}{l}\text { Defense } \\
\text { counsels } \\
\text { assessment }\end{array}$} & \multirow{2}{*}{\multicolumn{6}{|c|}{$\frac{\text { More effective plaintiff's counsels' assessment }}{n=9}$}} & \multicolumn{6}{|c|}{ Less effective plaintiff's counsels' assessment } \\
\hline & & & & & & & & & & $=43$ & & \\
\hline & \multicolumn{2}{|c|}{ Probable } & \multicolumn{2}{|c|}{ Uncertain } & \multicolumn{2}{|c|}{ Unlikely } & \multicolumn{2}{|c|}{ Probable } & \multicolumn{2}{|c|}{ Uncertain } & \multicolumn{2}{|r|}{ Unlikely } \\
\hline & $n$ & $\%$ & $n$ & $\%$ & $n$ & $\%$ & $n$ & $\%$ & $n$ & $\%$ & $n$ & $\%$ \\
\hline Probable & 6 & 100 & -- & -. & -- & - & 13 & 65.0 & 6 & 30.0 & 1 & 5.0 \\
\hline Uncertain & 2 & 100 & -. & -- & -- & - & 7 & 70.0 & 2 & 20.0 & 1 & 10.0 \\
\hline Unlikely & 1 & 100 & -- & -- & -- & 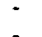 & 7 & 53.8 & 3 & 23.1 & 3 & 23.1 \\
\hline
\end{tabular}

NOTE: Cases consist of North Carolina state court medical malpractice cases filed between 1991 and 1995, inclusive, in which data are available from court files, interviews, the risk management office of a major teaching hospital, and from one of the principal liability insurers of physicians in North Carolina. 
Table 6 looks at case-picking as a shorthand for whether the presence of a trial was related to the insurers' assessment of liability controlling for attorney effectiveness. In short, are more effective attorneys better at evaluating liability and therefore settling the case, thus avoiding a trial? More effective attorneys went to trial in four out of sixteen $(25 \%)$ of their cases. They went to trial in only one of the nine cases $(11.1 \%)$ that was evaluated by the insurer as having probable liability, but went in two of the five $(40 \%)$ cases evaluated by the insurer as having uncertain liability, and one of the two cases $(50 \%)$ that the defense counsel evaluated as having unlikely liability. It seems clear that the more effective attorneys are picking the good cases and only bringing those to trial if the parties do not settle.

TABLE 6.

Case-Picking in Terms of Level of Liability and Presence of a Trial by Attorney Effectiveness

\begin{tabular}{|c|c|c|c|c|c|c|c|c|}
\hline \multirow{4}{*}{$\begin{array}{c}\text { Insurers' assessment } \\
\text { of liability }\end{array}$} & \multicolumn{4}{|c|}{ Less effective attorneys } & \multicolumn{4}{|c|}{ More effective attorneys } \\
\hline & \multicolumn{4}{|c|}{ Trial $n=73$} & \multicolumn{4}{|c|}{ Trial $n=16$} \\
\hline & \multicolumn{2}{|c|}{ Yes } & \multicolumn{2}{|c|}{ No } & \multicolumn{2}{|c|}{ Yes } & \multicolumn{2}{|c|}{ No } \\
\hline & $n$ & $\%$ & $n$ & $\%$ & $n$ & $\%$ & $n$ & $\%$ \\
\hline Probable & 6 & 18.2 & 27 & 81.8 & 1 & 11.1 & 8 & 88.9 \\
\hline Uncertain & 5 & 35.7 & 9 & 64.3 & 2 & 40 & 3 & 60 \\
\hline Unlikely & 9 & 34.6 & 17 & 65.4 & 1 & 50 & 1 & 50 \\
\hline
\end{tabular}

NOTE: Cases consist of North Carolina state court medical malpractice cases filed between 1991 and 1995, inclusive, in which data are available from court files, interviews, the risk management office of a major teaching hospital and from one of the principal liability insurers of physicians in North Carolina.

Less effective attorneys went to trial in twenty of seventy-three cases $(27.4 \%)$. Compared to more effective attorneys, they went to trial more often in cases evaluated as having probable liability by the insurer (six out of thirty-three, $18.2 \%$ ). However, they went less often in cases evaluated as having uncertain liability (five of fourteen, 35.7\%), and less often in cases evaluated as being of unlikely liability (nine of twenty-six, 34.6\%). Statistics are not reported because of small sample size.

Tables 7 and 8 further clarify the findings in the bivariate and multivariate analyses. Although the results of Fisher's exact test (appropriate for small numbers) are reported here, caution must be taken in drawing conclusions since the numbers are very small. In Table 7, the payment of money is analyzed in terms of whether there was agreement of assessment of liability or not. Table 8 goes a step farther, looking at the question of whether having handled four or more cases matters.

In Table 7 there were twenty-four cases in which plaintiffs' and defense counsel agreed about liability. In the nineteen cases in which there was 
agreement that liability was probable, money was paid to the plaintiff in eighteen $(94.7 \%)$ of the cases. Money was paid in both $(100 \%)$ of the cases in which there was agreement that liability was uncertain. In the three cases in which there was agreement that liability was unlikely, no money was paid to the plaintiff.

When there was disagreement with the defense's assessment of probable liability, money was paid to the plaintiff in four of seven cases $(57.1 \%)$. Disagreement with the defense's assessment of uncertain liability resulted in money being paid to the plaintiff in seven of nine cases $(77.8 \%)$ and in four of eleven $(36.4 \%)$ cases in which there was disagreement with the defense's assessment of unlikely liability. Fisher's exact test shows whether the independent variable makes a significant difference in the dependent variable and is appropriate for small numbers. The results are reported $(p<0.01, V=0.846)$, although the percentages are more suggestive. In sum, agreement makes for predictable outcomes, with a very high likelihood of money being paid when liability is probable or uncertain, while disagreement leaves the outcome uncertain.

TABLE 7.

Money Paid to the Plaintiff by Whether There Was Agreement Between Defense and Plaintiffs' Counsel on Assessment of Liability

\begin{tabular}{|c|c|c|c|}
\hline \multirow{2}{*}{\multicolumn{4}{|c|}{ Money paid }} \\
\hline & & & \\
\hline \multicolumn{4}{|c|}{ Agreement on liability } \\
\hline Probable & 18 & 94.7 & 19 \\
\hline Uncertain & 2 & 100.0 & 2 \\
\hline Unlikely & - & - & 3 \\
\hline \multicolumn{4}{|c|}{ Disagreement on liability } \\
\hline Probable & 4 & 57.1 & 7 \\
\hline Uncertain & 7 & 77.8 & 9 \\
\hline Unlikely & 4 & 36.4 & 11 \\
\hline
\end{tabular}

Fisher's exact test $=18.582, \mathrm{df}=5, p<0.01, \mathrm{~V}=0.846$

NOTE: Cases consist of North Carolina state court medical malpractice cases filed between 1991 and 1995 , inclusive, in which data are available from court files, interviews and the risk management office of a major teaching hospital and from one of the principal liability insurers of physicians in North Carolina. Where the assessments differed, the insurers' assessment of the liability is used to classify the cases.

Table 8 examines combinations of agreement on liability and malpractice case experience (fewer than four cases handled during the study period compared to four or more cases). This is intended to separate the impact of agreement on liability from medical malpractice case experience. In summary, Table 8 looks at the relationship between the plaintiff's counsel's ability to agree with the insurer's assessment of liability and the payment of money to the plaintiff for two groups of plaintiffs' counsel-those who had handled at least four cases and those who had not. Again, because the numbers are small the results should be viewed cautiously. Nonetheless, of the ten cases in which there was agreement that liability was probable or uncertain, in combination with counsel having handled four or more medical malpractice cases, money was paid to the plaintiff $100 \%$ of 
the time. Plaintiffs' counsel who had handled four or more cases simply did not select cases that both sides evaluated as having unlikely liability.

In those cases in which there was agreement about probable liability but plaintiffs' counsel had handled fewer than four cases, money was paid in eight of nine $(88.9 \%)$ cases. Money was also paid in the one case in which there was agreement that liability was uncertain. Those plaintiffs' counsel with less experience handled three cases in which there was agreement that liability was unlikely and in these cases, no money was paid to the plaintiff. The results of Fisher's exact test are reported $(p<0.001, V=0.856)$, showing that agreement with the insurer's assessment of liability is associated with the payment of money to the plaintiff. This pattern is more pronounced if counsel had handled at least four cases.

TABLE 8.

Money Paid to the Plaintiff by Agreement Between Defense and Plaintiffs' Counsel on Assessment of Liability and Medical Malpractice Case Experience

\begin{tabular}{|c|c|c|c|}
\hline & \multicolumn{2}{|c|}{$\begin{array}{c}\text { Money paid } \\
(n=20)\end{array}$} & \multirow[t]{2}{*}{ Total } \\
\hline & $\mathrm{n}$ & $\%$ & \\
\hline \multicolumn{4}{|c|}{ Agreement on liability: } \\
\hline \multicolumn{4}{|c|}{ Those with $\geq$ four cases } \\
\hline Probable & 10 & 100.0 & 10 \\
\hline Uncertain & 1 & 100.0 & 1 \\
\hline Unlikely & - & - & 0 \\
\hline \multicolumn{4}{|c|}{ Those with < four cases } \\
\hline Probable & 8 & 88.9 & 9 \\
\hline Uncertain & 1 & 100.0 & 1 \\
\hline Unlikely & - & - & 3 \\
\hline
\end{tabular}

NOTE: Cases consist of North Carolina state court medical malpractice cases filed between 1991 and 1995, inclusive, in which data are available from court files, interviews and the risk management office of a major teaching hospital and from one of the principal liability insurers of physicians in North Carolina. Where the assessments differed, it is categorized according to the insurance company's assessment

\section{DISCUSSION}

We have looked at the variables that previous literature reported as having an impact on whether money was paid in medical malpractice cases. In our analyses we have considered the impact of three categories of independent variables: relevant experience variables (years in practice and medical malpractice case experience), case context variables (severity of alleged injury and the occurrence of a trial), and finally, the insurer's assessment of liability.

Our analysis has proceeded in several stages. First, we conducted bivariate analyses of the impact of these three categories of variables on whether money was paid to the plaintiff using Chi-square and appropriate measures of association (Table 2). We found some evidence that malpractice case experience for the plaintiff's attorney had an impact on the payment of money to the 
plaintiff. In our bivariate analyses, the variables that were clear predictors of money being paid to the plaintiff were the insurers' assessment of liability and whether there was a trial. If insurers evaluated the liability of a case as probable or uncertain, money was frequently paid. If the case went to trial, it was unlikely that money would be paid. This finding should not be surprising. Insurers tend to settle the cases they believe present a substantial risk of liability, and cases in which the insurer makes an offer of settlement usually settle-regardless of the amount of the first offer. ${ }^{73}$ In short, when a case goes to trial, it is because the insurer has chosen not to make an offer of settlement-meaning the insurer has concluded that the case can be won. ${ }^{74}$ The ability of insurers to do this sort of case-picking successfully is borne out in the consistently high percentage of defense "wins" at trial reported by researchers. ${ }^{75}$

Next, we utilized binary logistic regression (Table 3) to evaluate the impact of these three categories of variables, relevant experience variables, case context variables, and insurers' assessment of liability, entering them in three separate models. Consistent with the bivariate analyses (Table 2), the presence of a trial and assessment of liability emerged in the multivariate analyses as significant predictors, again, along with evidence that plaintiffs' malpractice case experience was having some impact. Severity of the plaintiff's alleged injury was not a significant predictor of money being paid to the plaintiff.

Finally, we took an in-depth look at the relationships among plaintiffs' counsel's effectiveness, medical malpractice experience, agreement with insurers' evaluations of liability, and case outcome (Tables 4-8). Because these samples are very small, conclusions must be cautiously suggested. Recalling that the insurers' evaluations drive the process, our analyses indicate that the ability of plaintiffs' counsel to pick cases-that is, to evaluate liability as the insurer does-is crucial. Effective plaintiffs' counsel clearly do better at case-picking than less effective counsel.

It also seems that just picking the cases is not enough. Plaintiffs' counsel who had handled at least four cases were more likely to obtain money for the plaintiff, regardless of whether their assessments agreed with that of the defense, than those plaintiffs' counsel who had not handled at least that many cases during the study period. We suggest that the ability to evaluate cases as the insurer does is a necessary but not sufficient condition for money being paid to the plaintiff. In short, we find evidence that being a repeat player matters independent of whether plaintiffs' counsel is good at evaluating cases.

There is another aspect to our findings. While "empathic" case selection is important, the process of case resolution is not one-dimensional. ${ }^{76}$ The central

73. Peeples, Harris \& Metzloff, supra note 23 , at 887.

74. Id. at 894 .

75. Peters, supra note 70, at $1459-60$. Professor Peters also provides a very useful summary of research over the past three decades on the subject of jury-expert agreement.

76. By "empathic" we simply mean the ability of the plaintiff's counsel to assess a case the 
event in the resolution process is the insurer's assessment of liability, based on a number of factors. ${ }^{77}$ The traditional tort law requirements of breach of standard of care and causation ${ }^{78}$ are of obvious importance, but other factors become relevant as well. The identity of the plaintiff's counsel matters, as does the insurer's view of the witness potential of the plaintiff and the defendant physician. ${ }^{79}$ Since plaintiff's counsel will not know all that the insurer knows ${ }^{80}$ particularly the substance of the internal reviews the insurer has conducted-how does plaintiff's counsel make his or her decisions? A large part of the answer may be that an experienced plaintiff's counsel can make many of the same strategic assessments that the insurer can. Plaintiff's counsel will know his or her own prior experience with the insurer, for example-and reputation matters. The insurer is aware of the identity of the plaintiff's counsel, and how he or she has fared over time in other cases involving the insurer, and in malpractice cases not involving the insurer. With experience, furthermore, plaintiff's counsel will be adept at estimating the witness potential of his or her client. There is also the fact that an experienced plaintiff's counsel should know what will be required to prove the case, beyond the evidence of the medical records: for example, credible expert witnesses, a sympathetic story line, and the supporting testimony of family or subsequent treating physicians. Knowing what will be required to prove the case, however, is largely a function of knowing what will be necessary to persuade the insurer to seek a settlement-empathic case selection, in other words.

In the end, meaningful discussion of how the medical malpractice claims process might be reformed ought to be based on a thorough understanding of how the existing process really operates. Experienced plaintiffs' lawyers"repeat players"-operate as the gatekeepers to the medical malpractice liability system. In this specialized area of litigation, the reputations of plaintiffs' lawyers are known to the insurers. Experienced plaintiffs' lawyers understand what will be required in order to obtain a payment from the insurer. Thus experienced plaintiffs' lawyers play an important role in filtering out non-meritorious casesby and large, those cases are left to other lawyers. Because of their repeat player status, the decisions of experienced plaintiffs' lawyers-specifically, as to which cases to take and which cases to reject-are rational, based on an expectation of

way the insurer would. On the importance of empathy in negotiations generally, see Robert H. Mnookin, Scott R. Peppet \& Andrew S. Tulumello, The Tension Between Empathy and Assertiveness, 12 NEG. J. 217 (1996).

77. Harris, Peeples \& Metzloff, supra note 10, at 471-72, 492; Peeples, Harris \& Metzloff, supra note 23 , at $893-94$.

78. DOBBS, supra note 30, § 242; WELLER ET AL., supra note 15, at 19.

79. Harris, Peeples \& Metzloff, supra note 10.

80. The internal reviews conducted by the insurer are confidential and not subject to discovery. It is not uncommon, however, for plaintiffs' counsels who specialize in medical malpractice to have their own medical professionals, such as registered nurses, on staff or under contract. 
compensation both for their clients and themselves. Is the involvement of experienced plaintiffs' counsel worth the price? That answer is beyond the scope of this Article. Perhaps a "no-fault" system would lessen the value of being represented by a repeat player. However, under a system that assumes the potential involvement of a lay jury, and that is premised on "fault," the function of experienced plaintiffs' counsel is essential.

\section{CONCLUSION}

The medical malpractice compensation system may be inefficient, but it is rational. Meritorious claims are more likely to be paid than non-meritorious claims. The status of plaintiff's counsel as a repeat player, skilled at evaluating cases, is the basis for the system's rationality. In this Article, we have attempted to provide a more detailed picture of the claims resolution process in medical malpractice by focusing not just on trial but also on settlement, and by looking at the attributes that predict a claim's outcome. Breach of the standard of care matters, as does causation. Other factors also make a difference. High on the list of other factors is the experience level of plaintiff's counsel because it informs his or her case-picking ability.

A larger, random sample, including both quantitative and qualitative data, is necessary for a continuing analysis of the important variables that have an impact on case outcome, as well as the litigation process itself. More information on actual settlement amounts would also advance our understanding of the claims resolution process. For example, by controlling for severity of injury, it might be possible to compare the effectiveness of plaintiff's counsel with more precision, and to isolate the repeat player effect in more detail. 